\title{
Influence of Early Childhood Instructional Supervision on Caregivers' Effectiveness in Federal Capital Territory Centers, Abuja Nigeria
}

\author{
Eunice Bose Oke \\ University of Abuja, Abuja, Nigeria
}

\begin{abstract}
The selection and use of curriculum can either facilitate or hinder Care-Giver performance in early childhood education centers. Thus the study examined the extent to which instructional supervision relate to Care-Giver performance in, Federal Capital Territory, Abuja. The research design is descriptive survey. Six Area Councils were purposively selected for the study. Stratified random sampling was adopted to select 25 centers representing 12percent of the entire populations, as sample. Simple random sampling was used to select a Care-Giver from each center making a total of 25 Care-Givers as respondents. Two validated instruments tagged Instructional Supervisory Techniques Questionnaire (ISTQ), and Care-Giver effectiveness Questionnaire (CPQ) 'were used to collect relevant data for the study. Percentages and means were used to answer the research questions. The findings revealed that adequate supervision in the early childhood education assists caregivers in acquisition of new skills; help inexperienced care-givers to acquire new method of teaching and helps them identify children with learning impairment, though not done regularly. The researcher recommends that school heads should encourage frequent supervision of instruction in their various schools. Teachers who are well trained and have the knowledge of the theory and practical education should be recruited.
\end{abstract}

\section{Introduction}

Education as expressed by Akpa[3]is the biggest instrument for academic progress, social mobilization, political survival and effective national development of any country and constitutes the single largest enterprise in the country like Nigeria.

Early childhood education is thus considered as the foundation or the bed rock upon which other ties of education are built. According to National Policy on Education [12], it is an education given in an educational institute to children prior to their entering the primary school. It includes the crèche, nursery and kindergarten. Early childhood education may be

defined as the care, stimulation and instruction of children between three to five years of age in a preschool with their teachers and care givers. This period is very crucial as the first two years of their training are spent in the creation of a child's first sense of self or the building of the firs identity. It is important to note that early childhood period is a time of a remarkable brain development. It is the period when walking, talking, self-esteem, vision of the world and moral foundation is established. For this reason, education of young children must be effectively organized and pursued vigorously by the government through well-articulated programs. In order to achieve the stated goals of early childhood education and to lay good educational foundation for physical, emotional, mental, moral and cognitive development of a child, there must be adequate supervision of care givers for effective implementation the curriculum of early childhood education.

Care givers are the backbone of the entire educational system. Their efficiency is the most important factor affecting the future development of education process. Okeke [18] noted teachers are the most effective agents of change because they function as administrators, curriculum developers, instructors and career guidance counselors and mediators in all educational matters. Ukeje [32] also noted that if a child is the center of educational system, the teacher is the pivot of the educational process. Hence, supervision has been identified as one of the approaches to teacher effectiveness.

Supervision is designed to advise, guide, refresh, encourage and facilitate good achievement. In order for the school to achieve these goals, there should be a conducive child friendly environment where teaching and learning will take place. A child friendly school is a school where staff is friendly to children and the health and safety needs of the children are adequately met.

In any given situation, the environment has a major role to play if effective development will take place. Akubue [5] said that classroom environment for instance has a powerful influence on how well 
pupils achieve a wide range of educational outcomes. Goldhammer [12] also noted that classroom environment such as the physical, emotional and aesthetics characteristics of the classroom tend to enhance pupils attitude towards learning.

Hence effective supervision of instruction becomes indispensable for the attainment of educational objectives. To improve learning in schools, there should be functional internal (school heads) and external (government agents) supervisions. They however work together to achieve set objectives. Effective supervision therefore, remains the back bone for effective implementation of national curriculum for early childhood education.

Wiles [33] identified two types of supervision as internal and external supervisions. Internal supervision is carried out by the school heads e.g. principals, headmistress while external supervision is carried out by government agents. Adesina [1] proposed that external supervision is more effective in promoting teacher instructional effectiveness while external supervision are more conversant with the needs and problems of teachers.

\section{The Concept of Early Childhood Education}

Early childhood period is a crucial period in the development of any individual. A child, right from conception is a unique individual with his special characteristics and no children are completely alike in everything not even the identical twins. The early years from two to five years are critical in children's development. During this period, their physical, mental and cognitive development undergoes great changes making significant development. They move from dependence to independence improving marvellously on their motor skills control. They also move from their non-verbal communication to talking with people. During this period they enjoy playing, listening to stories, songs, imitating and learning, trying out new things and enjoying in adventure. They also learn to trust adults more and build partnership with their playmates. Early childhood period is very crucial in any individual and taken to lay good foundation for a child so as to grow into his full potential and contribute positively to the society.
In early childhood years, the importance of teaching, supervision of early childhood instruction, care-givers effectiveness cannot be over-emphasised. It is at this stage of basic education that the principal attitudes towards learning as well as the self-image of the leaner are formed. The role of a teacher at this time is very crucial. The demands on teacher's competence, professional and dedication impose on them enormous responsibility. Teachers' relationship with the leaner remains central to the teaching process.

\section{The Objectives of Early Childhood Education}

The objectives of early childhood education as enumerated in the National policy on education [12] among others include:

i. Effecting a smooth transition from the home to the school.

ii. Preparing the child for the primary level of education.

iii. Providing adequate care and supervision for the children while their parents are at work.

iv. Inculcating in the child the spirit of enquiry and creativity through the exploration of nature and the local environment playing with toys.

v. Teaching the rudiments of numbers, letters, shapes, colours, forms, etc. through play.

vi. Teaching good habits especially good habits.

These objectives cover the developmental aspects of the cognitive, the affective and psychomotor domains.

\section{The Concept of Instructional Supervision}

Supervision is an activity designed to oversee the works done by the individual teachers to assist them to perform better. It is designed to advise, guide, refresh, stimulate, encourage and facilitate goal achievement. Individuals charged with advisory functions have the responsibility of planning, directing and controlling various activities for 
achievement of predetermined goals. Ijeoma and Nwagwu [22] views supervision as one of the requirements of administration that concerns itself with the tactics of efficiency and effective management of human and natural resources. Supervision if well managed an executed would achieve uniformity in care delivery, capacity building on the part of the care-givers as enhance cooperation between supervisors and care-givers. It has the tendency of ensuring effective implementation of the national curriculum for early childhood to maintain standard in delivery, ensue quality control, and identify deficiencies in curriculum content and implementation to bring school and community to closer end and more productive relationship. Wellsupervised early childhood care delivery provides inservice training for care-givers, strengthens data base as record are properly kept.

Functionally, supervision concerns itself with the process of improvement and enhancement performance. To be effective a care-giver must draw upon a broad range of teaching skills as well as on the human quality of empathy, patience and humility as a component to the authority. When a child's first teacher is poorly trained and motivated, the very foundation on which all subsequent learning will be built will be unsound, so teacher education is very crucial. Wiles [33] identified two types of supervision as internal and external supervision. Internal supervision is carried out by the school heads e.g. principals while external supervision is carried out by government agents. The purpose of supervision is not to find fault or to punish rather to work cooperatively with the teacher.

The concept of the instructional supervision is that phase of school administration which focuses primarily upon the achievement of the appropriate of expectations of educational system. It is practical demonstration by the supervisor: this is a strategy in which a supervisor is an indispensable aspect of supervision which focuses on teaching and learning activities for the achievement of objectives in the schools. According to Aguba[2] defined it as behaviour officially designed by the organisation that directly affects teachers'behaviour in such a way as to facilitate pupils' learning and achievement of goals of the organisation. According to Peretomode[20], it is basically concerned with supporting and assisting teachers to improve instructional activities. It is obvious therefore that instructional supervision raises quality of instruction, enhances teaching and learning as well as facilitates the achievement of the set goals in the school system

Ukeje [32] defined instructional supervision as a collaborative effort involving a set of activities designed to improve the teaching and learning process. The act of teaching and learning is supervised to see that the desired objectives are achieved. During the supervision, subjects are examined in relation to teaching methods applied, instructional materials available for use and teacher himself in terms of qualification and training. Instructional supervision is very important because it has direct bearing on the pupils, teachers, curriculum and instruction.

\section{Techniques of Instructional Supervision}

- Peretomode [19] outlined activities that skilful instructional supervisor can utilize to bring about desirable effect in teacher behaviour for achieving teaching effectiveness. These include: orientation meeting: this is very necessary to assist caregivers improve and function at an acceptable quality level. During this meeting, care-givers are furnished with necessary information for coping with challenges involved in caring for fragile group of human beings. Udeozor [31] noted that nothing is as frustrating to workers especially newly employed as being ignored and left uninformed about the organisation.

- Classroom observation involves observing a teacher and analysing his or her classroom practices, the teaching learning processes, teachers' personality, pupils teacher interactions, lesson note and lesson presentation. All these are observed by the supervisor who is present as a witness. Experienced person explains or practically demonstrates a skill or a certain therapeutic preparation while caregivers observe and take notes. The effectiveness of this strategy depends on the awareness of the purpose by the observer. 
- Capacity building workshops: This is organised to improve performance through the acquisition of new knowledge, insights, skills and competencies. This activity involves a small group of people temporary formed to discuss a specific topic trying to find solutions to a specific problem in face- toface situation.

- Listening to tapes, radio or recordings: this involves using sound recordings to present ideas to one or more listeners in such a way as to help develop understanding or skills. The use of visual presentations through the media; film, television, video tape are increasingly important in the supervisory process.

- Guided practice: this supervision technique involves individuals or small group manipulative activities. It is an approach in which doing is more emphasised rather than talking with practice activities arranged out of context. The need for instructional supervision for quality assurance is plea for the cooperation of all educational stakeholders towards a more efficient achievement of the task goal. The quality of education can be actualized where the educational system is reliable and this reliability can only be achieved through both instructional and personnel supervision by the principals. The role of the principals is to facilitate the implementation of the various sets of instructional activities that will improve the teaching- learning situation in the input process.

It is necessary to note that supervision of teachers is comprehensive on-going process of facilitating teacher's professional growth and development on their career. Quality teacher supervision is critical for staffmembers can receive continuous support in their development as professionals and Para- professionals and thus become better providers of care and education for children.

\section{Pupil's learning environment}

Educational environment is used to describe surroundings, circumstances and influences affecting the child's systematic training and instruction. It is a place where the teaching and learning process occur. The extent of learning achieved depends largely on the organisation of the immediate educational environment, teacher child interactions, resources and school readiness activities provided within edu-care pre-school settings.

The quality of pupil's learning environment is directly related to the quality of classroom instruction. Early childhood learning environment is the types that consist of various activities and play centres. It is the duty of the supervisor therefore to facilitate the matching of material arrangement with curricular provisions in the areas of play, language, science, mathematics, arts, music and health habits. Akubue [5] opined that the early childhood learning environment should be: physically safe, clean and healthy, emotionally warm and supportive, comfortable and functional, rich in sensory motor and social experiences, available for extensive exploration, consistent and predictable.

The learning environment of early childhood care should be physically and socially sound. The surroundings must be attractive enough to arouse learning. Early childhood care-givers should be guided on improvisation. It is a challenge upon the supervisor of early childhood to ensure a conducive and friendly environment for pupils. Also the supervisors of early childhood care-givers need to be open minded, tolerant, approachable, neat, friendly, humble, knowledgeable, understandable and highly competent. This ability will attract much respect from the care-givers.

\section{Caregivers' Preparation and Quality}

The educational system in Nigeria today requires innovative creative and well-trained teachers who have the correct attitude and approach towards their jobs. Considering the important nature of pre-primary education, the issue of quality must of necessity be brought to the fore especially as low quality has been identified as one of the problems that characterise the Nigerian educational system Anya [4]. There is need for adequate teacher preparation for the achievement of educational goals and objectives.

Adequate teacher preparation is a necessity and since education is a positive partner in progress and development, no meaningful development can however take place in any nation without adequate human power resources in every area of endeavour. 
Building human capital has been recognised in recent times as crucial to the development and progress. The important of developing human capital cannot overemphasise as it acts as a catalyst for change for a better future for individuals to realise their full potentials in the acquisition of knowledge and skills. Education is hardly qualitative either because of the poor quality of teachers, the non-provision of the right type of equipment etc.

According to Lockheed and Vespoor [15], providing quality education for children is a prerequisite for developing the human resources base required to the changing technological demands of the twenty first century. However, Nwagbara [20] notes that improvement should actually start at pre- primary level where children are expected to develop their basic attitudes and approaches to learning. Collaborating with this view, Anya[4] asserts unless the foundation for learning is laid in the pre-primary school age, the individual's ability to take full advantage of the learning environment of the education system later in life is contained right from the onset. Training of teachers is important in the achievement of school goals and objectives. If teachers as human resource developers do not undergo on the job training or orientation from time to time, their knowledge will become obsolete Nwagbara [20]. According to Ejiogu [10] opined that every staff development programme should aim at each participant havingability to contribute his very best.It is to find out whether or not instructional supervision facilitate or hinder care givers effectiveness in Federal Capital Territory, Early Childhood Education Centres across the six area councils.

The aims include the following; to examine the extent to which the various supervisory techniques wereadopted for instruction, to find out the extent to which instructional supervision enhance caregivers acquisition of skill and knowledge for effective delivery, to find out the extent to which instructional supervision support care givers ability in creating conducive learning environment and to examine the extent to which instructional supervision assist care givers knowledgein promoting children learning ability.

The study is guided by the following research questions; i. To what extent are the various types of supervisory techniques effectively adopted for instruction in ECEC in FCT, Abuja?

ii. To what extent do the instructional supervision techniques adopted enhance care givers acquisition of knowledge and skills for effective delivery in ECEC in FCT, Abuja?

iii. To what extent do instructional supervision assist care givers skill in creating conducive physical learningenvironment in ECEC in FCT, Abuja?

iv. To what extend do instructional supervision facilitate caregivers' skill in promoting children learning ability in ECECin FCT, Abuja?

v. To what extent does instructional supervision help caregivers in adequate selection of appropriate facilitiesin ECECin FCT, Abuja?

vi. To what extent do instructional materials enhance caregivers in use of appropriate methods of teachingin ECECin FCT, Abuja?

\section{Methodology}

The research designed is descriptive survey with emphasis on correlation of variables on instructional supervisorytechniques (independent variable) and caregivers' effectiveness (dependent variable). The purposive random sampling technique was used to choose all the six Area councils in Federal Capital Territory, Abuja; which form the target population for the study.The stratified random sampling technique was adopted to select $12 \%$ of the entire population from 212 centers to give a sample of twenty five centers. The simple random samplingtechnique was adopted to select a total of 25 care giversfrom the entire 170 care givers representing $43 \%$.

Two instruments titled "Instructional SupervisoryTechniques Questionnaire (ISTQ) consisted supervisory activities with 10-item questions and "Care givers Effectiveness Questionnaire (CEQ)" were administered for data collection.The latter focused on roles of the Care givers as required by the National ECEC curriculum guide which consists 35-item questions. The respondents were to score all the items ofthe fortyfivequestions on a scale of four points modifiedLikert ratingscale with scores ranging between 1 and 4 as follow; Very High Extent (VHE) 4, High Extent (HE) 
3, Low Extent (LE) 2, Very Low Extent (VLE) 1. Teachers are respondents.

The items of the questionnaireswere faced and content validated by Early Childhood Education and curriculum specialists. The instruments were pilottested in one of the early childhood education centers, in Suleja, Niger state, a neighboring state.

The reliability was determined using split-half method. The instruments were administered to randomly selected twenty (20) caregivers. The scores were determined using the Spearman Brown'sformular called the coefficient of equivalence. The instrument yielded high degrees of 0.70 and 0.71 reliability. All research questions were answered through mean scores and standard deviation. Mean scores above 2.51 is accepted as positive while those below are rejected as negative.

\section{Data Presentation}

Table 1 has nine items that measured the instructional supervisory techniques.From the analysis, there is onevery high extent with mean score of (3.60), fivelow extentswith mean scoresranging from (1.20-2.20) and two very low extent with mean scores ranging from (1.12-1.20).

Table 1. Instructional Supervisory Techniques

\begin{tabular}{|l|l|l|l|l|l|}
\hline S/N & $\begin{array}{l}\text { Supervisory } \\
\text { Techniques }\end{array}$ & $\mathrm{N}$ & Sum & Mean & $\begin{array}{l}\text { Decisio } \\
\mathrm{n}\end{array}$ \\
\hline 1 & $\begin{array}{l}\text { Orientation } \\
\text { meeting }\end{array}$ & 25 & 51 & 2.04 & LE \\
\hline 2 & $\begin{array}{l}\text { Classroom } \\
\text { Observation }\end{array}$ & 25 & 90 & 3.60 & VHE \\
\hline 3 & $\begin{array}{l}\text { Practical } \\
\text { demonstration }\end{array}$ & 25 & 53 & 2.12 & LE \\
\hline 4 & $\begin{array}{l}\text { Capacity building } \\
\text { workshops }\end{array}$ & 25 & 42 & 1.70 & LE \\
\hline 5 & $\begin{array}{l}\text { Listening to tapes, } \\
\text { radios \& recording }\end{array}$ & 25 & 46 & 1.85 & LE \\
\hline 6. & $\begin{array}{l}\text { Guided practice } \\
8 .\end{array}$ & 25 & 28 & 1.12 & VLE \\
\hline 9. & Done Regularly & 25 & 45 & 1.81 & LE \\
\hline Total & External & 25 & 55 & 2.20 & LE \\
\hline
\end{tabular}

This simply means that the levels of the use of instructional supervisory techniques were adapted to a low extent with average mean score of (1.96). From these responses should be noted that instructional supervision is anessential educational activity needed for improved teaching and learning.

Table 2. Acquisition of Knowledge and Skills

\begin{tabular}{|c|c|c|c|c|c|}
\hline $\mathrm{S} / \mathrm{N}$ & $\begin{array}{l}\text { Promote } \\
\text { knowledge \& skills } \\
\text { acquisition }\end{array}$ & $\mathrm{N}$ & Sum & Mean & $\begin{array}{l}\text { Deci } \\
\text { sion }\end{array}$ \\
\hline 10 & $\begin{array}{l}\text { Evaluation } \\
\text { instructions }\end{array}$ & 25 & 86 & 3.44 & $\mathrm{HE}$ \\
\hline 11 & $\begin{array}{l}\text { Demonstration } \\
\text { friendliness }\end{array}$ & 25 & 90 & 3.60 & VHE \\
\hline 12 & $\begin{array}{l}\text { Humorous and } \\
\text { persuasive } \\
\text { character }\end{array}$ & 25 & 78 & 3.12 & $\mathrm{HE}$ \\
\hline 13 & $\begin{array}{l}\text { Answers } \\
\text { instructional } \\
\text { problems }\end{array}$ & 25 & 85 & 3.40 & $\mathrm{HE}$ \\
\hline 14 & $\begin{array}{l}\text { Possess knowledge } \\
\text { of schools } \\
\text { programmes } \\
\text { Improved } \\
\text { inexperienced } \\
\text { teachers } \\
\text { Identify learning } \\
\text { problems }\end{array}$ & 25 & 89 & 3.56 & VHE \\
\hline & & 25 & 80 & 3.20 & $\mathrm{HE}$ \\
\hline & Total & 175 & 597 & 3.41 & $\mathrm{HE}$ \\
\hline
\end{tabular}

Table 2 analyses the Instructional Supervision techniques on supporting caregivers' acquisition of skills and knowledge. It has seven items.From the analysis, three items 11, 14 and 15 items are rated to a very high extent with average mean of (3.56-3.60), four items were rated to a high extent; they are 10,12, 13 and 16 with mean scores ranging from (3.12-3.44), which indicates that supervisory techniques supports caregivers in acquiringskills and knowledge to a higher extent.

Table 3 has seven items that were used to portray the influence of instructional supervision on pupils learning ability. Two items depict very high extent (item 17, 18) with mean scores ranging from (3.563.80), Four items, 19, 20, 21, 22 scored high extent with mean score ranging from $(2.68-3.48)$ 
Table 3. Pupils learning ability

\begin{tabular}{|c|l|l|l|l|l|}
\hline S/N & $\begin{array}{l}\text { Support caregiver } \\
\text { to facilitate pupils' } \\
\text { learning ability }\end{array}$ & Sum & Mean & $\begin{array}{l}\text { Decis } \\
\text { ion }\end{array}$ \\
\hline 17 & $\begin{array}{l}\text { Promotes } \\
\text { interactive learning }\end{array}$ & 25 & 89 & 3.56 & VHE \\
\hline 18 & $\begin{array}{l}\text { Creates sense of } \\
\text { seriousness in } \\
\text { children }\end{array}$ & 25 & 95 & 3.80 & VHE \\
\hline 19 & $\begin{array}{l}\text { Creates trust in } \\
\text { children }\end{array}$ & 25 & 67 & 2.68 & HE \\
\hline 20 & $\begin{array}{l}\text { Assures children of } \\
\text { the teachers } \\
\text { capacity }\end{array}$ & 25 & 87 & 3.48 & HE \\
\hline 21 & $\begin{array}{l}\text { Children have } \\
\text { sense of belonging } \\
\text { cared for }\end{array}$ & 25 & 71 & 2.84 & HE \\
\hline 22 & $\begin{array}{l}\text { Arouses curiosity } \\
\text { in children }\end{array}$ & 25 & 78 & 3.12 & HE \\
\hline 23 & $\begin{array}{l}\text { Creates children } \\
\text { readiness }\end{array}$ & 25 & 57 & 2.28 & LE \\
\hline 24 & $\begin{array}{l}\text { Enhances children } \\
\text { holistic } \\
\text { development }\end{array}$ & 25 & 55 & 2.20 & LE \\
\hline Total & & 200 & 599 & 3.42 & HE \\
\hline
\end{tabular}

However there are two lowextent with a mean scoreranging from (2.20-2.28). Instructional supervision to a great extent influences pupils learning ability. While one item helps the children achieve social, emotional, physical and cognitive growth. This simply means that instructional supervision of caregivers is very essential for pupil's academic excellence.

Table 4 has six items that measured the influence of instructional supervisory techniques on caregivers' skills in creating conducive physical learning environment. From the analysis, there are three very high extents with mean score ranging from (3.523.60 ), three high extents in items 26, 28, 29 have mean scores ranging from (3.12-3.44). This simply means that instructional supervision to a high extent influences the caregivers' skills in creating conducive physical environment.

Table 5 shows six items that were used to ascertain the extent to which instructional supervision influences learning facilities which promote the general performance of pupils. From the analysis, three items were rated high extent in items 32,34 and 35 with mean scores ranging from (3.12-3.44), while items 33 and 36 are rated very high extent with mean scores ranging from (3.56-3.60), one item 37 is rated low extent with mean score of (2.48).

Table 4. Conducive physical Learning Environment

\begin{tabular}{|l|l|l|c|l|l|}
\hline S/N & $\begin{array}{l}\text { Support in } \\
\text { creation of } \\
\text { learning } \\
\text { environment }\end{array}$ & N & Sum & Mean & $\begin{array}{l}\text { Deci } \\
\text { sion }\end{array}$ \\
\hline 26 & $\begin{array}{l}\text { Promotes good } \\
\text { learning } \\
\text { environment }\end{array}$ & 25 & 86 & 3.44 & HE \\
\hline 27 & $\begin{array}{l}\text { Fosters children } \\
\text { enquiry } \\
\text { explorations }\end{array}$ & 25 & 90 & 3.60 & VHE \\
\hline 28 & $\begin{array}{l}\text { Creates neat, } \\
\text { calm \& relaxed } \\
\text { atmosphere }\end{array}$ & 25 & 78 & 3.12 & HE \\
\hline 29 & $\begin{array}{l}\text { Arouses } \\
\text { teachers interest } \\
\text { in classroom } \\
\text { aesthetic }\end{array}$ & 25 & 85 & 3.40 & HE \\
\hline 30 & $\begin{array}{l}\text { Identifies } \\
\text { teachers } \\
\text { unethical } \\
\text { conduct }\end{array}$ & 25 & 89 & 3.56 & VHE \\
\hline 31 & $\begin{array}{l}\text { Promotes } \\
\text { friendly learning } \\
\text { environment }\end{array}$ & 25 & 88 & 3.52 & VHE \\
\hline Total & 150 & 516 & 3.44 & HE \\
\hline
\end{tabular}

Table 5. Instructional Supervision on Pupils Learning Facilities

\begin{tabular}{|c|c|c|c|c|c|}
\hline $\mathrm{S} / \mathrm{N}$ & $\begin{array}{l}\text { Selection of } \\
\text { adequate } \\
\text { facilities }\end{array}$ & $\mathrm{N}$ & Sum & Mean & $\begin{array}{l}\text { Deci } \\
\text { sion }\end{array}$ \\
\hline 32 & $\begin{array}{l}\text { Selecting of } \\
\text { adequate } \\
\text { learning } \\
\text { facilities }\end{array}$ & 25 & 86 & 3.44 & $\mathrm{HE}$ \\
\hline 33 & $\begin{array}{l}\text { Develops } \\
\text { positive feelings } \\
\& \text { disposition }\end{array}$ & 25 & 90 & 3.60 & VHE \\
\hline 34 & $\begin{array}{l}\text { Children learn } \\
\text { and discover } \\
\text { talents }\end{array}$ & 25 & 78 & 3.12 & $\mathrm{HE}$ \\
\hline 35 & $\begin{array}{l}\text { Increase } \\
\text { children } \\
\text { learning ability }\end{array}$ & 25 & 85 & 3.40 & $\mathrm{HE}$ \\
\hline 36 & $\begin{array}{l}\text { Exposes } \\
\text { teachers to best } \\
\text { methods }\end{array}$ & 25 & 89 & 3.56 & VHE \\
\hline \multirow[t]{2}{*}{37} & $\begin{array}{l}\text { provision of } \\
\text { textbooks\& } \\
\text { other materials }\end{array}$ & 25 & 62 & 2.48 & $\mathrm{LE}$ \\
\hline & Total & 150 & 428 & 3.42 & $\mathrm{HE}$ \\
\hline
\end{tabular}


It clearly indicates that instructional supervision of care-givers is very essential for improvement of teaching and learning.

Table 6. Influence of Instructional Supervision on Caregivers use of methods

\begin{tabular}{|c|c|c|c|c|c|}
\hline $\mathrm{S} / \mathrm{N}$ & $\begin{array}{l}\text { Caregivers' use } \\
\text { of methods }\end{array}$ & $\mathrm{N}$ & Sum & Mean & $\begin{array}{l}\text { Deci } \\
\text { sion }\end{array}$ \\
\hline 38 & $\begin{array}{l}\text { Lecture/Demons } \\
\text { trations }\end{array}$ & 25 & 89 & 3.50 & VHE \\
\hline 39 & $\begin{array}{l}\text { Field trips and } \\
\text { films }\end{array}$ & 25 & 48 & 1.94 & LE \\
\hline 40 & $\begin{array}{l}\text { Recitation and } \\
\text { Questioning }\end{array}$ & 25 & 66 & 2.64 & $\mathrm{HE}$ \\
\hline 41 & Discussion & 25 & 80 & 3.22 & $\mathrm{HE}$ \\
\hline 42 & $\begin{array}{l}\text { Games/Simulati } \\
\text { on }\end{array}$ & 25 & 30 & 1.23 & VLE \\
\hline 43 & Role playing & 25 & 55 & 2.20 & LE \\
\hline 44 & $\begin{array}{l}\text { Independent } \\
\text { study }\end{array}$ & 25 & 75 & 3.00 & $\mathrm{HE}$ \\
\hline 45 & Textbooks & 25 & 90 & 3.60 & VHE \\
\hline 46 & Practices & 25 & 50 & 2.00 & LE \\
\hline 47 & inquiry & 25 & 38 & 1.52 & LE \\
\hline & Total & 250 & 591 & 2.36 & LE \\
\hline
\end{tabular}

Table 6 has ten items that measured the different types of methods the supervision assisted the caregivers to identify and appropriately apply in teaching. Items 38 and 45 were rated very high extent, with mean scores ranging from(3.50-3.60), items 40, 41,44 were rated high extent, with means score ranging from (2.64 - 3.22)while items 39, 43, 46 and 47 were rated low extent with means score ranging from $(1.52-2.20)$ and very low extent in item 42 respectively with mean scores (1.23).to low extent, instructional supervision enhanced care givers skills in identifying appropriate method of teaching with cumulative mean of 2.36 .

\section{Discussion of Findings}

Thus, this research work is aimed at discovering the influence of instructional supervision on caregivers' performance in FCT early childhood education centres.

The findings from the six research questions raised to guide the study revealed from twenty-five respondents in twenty five centres selected that: Instructional supervisory technique were adopted to a low extent in Federal Capital Territory early children centres with a cumulative average mean of 2.02 . Classroom observation was found to dominate in techniques adopted for supervision, both internal and external supervision were not regularly conducted in the various centres and other types of supervisory techniques were used at a very low extent.However, instructional supervision was found to promote care givers acquisition of skills and knowledge for effective delivery to high extent with average mean score of 3.42.Secondly, found to support caregivers in facilitating pupils learning ability with average mean score 3.391.Thirdly, it was found that instructional supervision enhance caregivers ability in creating conducive environment to a high extent with average mean score of 3.42.Fourthly, instructional supervision assist the caregivers in selecting appropriate facilities and teaching aids to a high extent with average mean of 3.Fifthly, instruction supervision enhanced caregiver's use of adequate methods to a low extent with average mean of 3 .

\subsection{The findings reveal the following attributes}

Instructional supervision is an indispensable aspect of supervision which focuses on teaching and learning activities for the achievement of educational objectives. That instructional supervision to a greater extent influences caregivers' skill and knowledge as observed from twenty five selected centres. It shows that it helps care-givers in the acquisition of skills for evaluation of instructions. It helps the inexperienced care-givers to improve their teaching. It helps them to create friendly and humorous environment for learning. It helps them to develop skills for identifying and teaching of children with learning difficulties as depicted in respondents' opinions. It actually supports the saying that blind does not lead blind. Supervisors whether internal or external has great role to play in education. They are the eyes 
through which teachers see. They serve as guide to staff development.

Pupils' learning environment still remains paramount in pupils learning achievement and has ability to shape their behaviour. The learning environment of early childhood should be physically and socially sound, stimulating, joyful, caring and secure. The surroundings must be attractive enough to arouse learning. Hence, from the findings it was very clear from the responses that were given by the respondents that instructional supervision helps caregivers to create a neat, calm and relaxed atmosphere for learning. It promotes good learning environment that helps children to inquire, explore the natural world. These have mean responses of 3.60, 3.56 , and 3.52 respectively which indicate that instructional supervisors have actually imparted positively in the learning environment of most schools especially the sampled ones in FCT centers.

Provision of friendly learning environment, well trained teachers, adequate learning facilities, adequate learning materials like, text books without supervision may not lead to the achievement of the targeted goal. Thus the study showed clearly the need for adequate instructional supervisions for maximum utilisation of both human and physical resources for higher learning achievement. Item numbers with mean responsesm3.44, 3.60, and 3.52supports the fact that instructional supervision supports interactive learning and encourages pupils' construction of language. It instils senses of seriousness to children to care more for their books. It also assists children to develop deep trust in their teachers and in them especially when external person assesses their learning materials. It creates room for competition and curiosity that is needed in achieving higher learning.

From the findings, the use of learning facilities in different centres of teaching and learning cannot be over-emphasised. The challenge is usually the availability of such facilities and management. Learning facilities has no doubt of its effect in general performance of pupils. The responses from this research work shows the extent to which supervision of these facilities affects children's performance. The mean responses $(3.44,3.40,3.56$, and 3.12) have shown that the use and supervision of learning facilities has helped children to develop their higher order abilities, thinking, reasoning and problem solving. It has helped children to discover and to develop their talents. It assists children's learning ability and retention. In fact, the research reveals that it exposes teachers on the best method to use the facilities in teaching children. One would imagine the extent of contributions if all the supervisory techniques were incorporated or integrated into supervision of instructions. In early childhood centres in Federal Capital Territory in Abuja, Nigeria.

\section{Conclusion}

Effective supervision of instructions in FCT early childhood centres isindispensable for the attainment of educational goals. It is the back bone to maintain education standard and effective implementation of national curriculum for early childhood education. Instructional supervision continues to be essential tool for improving teacher quality which affects children's performance in all ramifications. It helps to identify and improve teachers with poor teaching skills as well as to determine those with special abilities. It helps to determine quality of instruction and identify areas of urgent needs in various schools.It can therefore be concluded that the instructional supervision is inevitable in our centers for improved teaching and learning. This is because the finding reveals that it helps to identify care-givers strength and weaknesses; those with poor teaching skill who would be assisted to improve their knowledge and skill for better performance. Supervision of care-givers helps them to imbibe demonstrating, friendly, humorous and pervasive character during instruction. It has ability to help in creating a positive learning environment that nurtures each child's growth, independence and a love of learning that creates a foundation for success in school and their future lives. For any meaningful teaching and learning to occur, supervision must be encouraged in all centers, for it is an indispensable tool for caregivers' effectiveness.In conclusion, caregiver's effectiveness would be highly improved and enhanced if the other types of supervisory techniques are integrated into classroom observation for instructional supervision in Federal Capital Territory early childhood education centres. 


\section{Recommendations}

Based on the findings of this study, the following recommendations are made with hope that their implementation will help to improve teaching and learning in FCT early childhood education centres.

i. Centre heads should increase their level of involvement and commitment in instructional supervision.

ii. The department of implementation policy (DPI)in-charge of supervision should also show a high level of commitment and involvement to instructional supervision in early childhood centre.

iii. Both internal and external supervisor should improve the frequency of instructional supervision in FCT ECEC Centres.

iv. Integration of all types of instructional supervisory techniques should be enhanced and implemented for effective supervision

v. Government should make facilities available for professional training of supervisors and caregivers.

\section{References}

[1] Adesina, S., (1990). Introduction to Educational Planning, Ile-Ife: University of Ife Press.

[2]Aguba, C.R., (2009). Educational Administration and Management- Issues and Perspectives. Enugu: Tons and Tons PDS Publishers.

[3]Akpa, G.O. (Ed.), (2002). The $1^{\text {st }}$ Century Principal in Nigeria. Jos: Ichejim Publications.

[4] Anya O. Anya, (1999). "Educating Nigeria for the $21^{\text {st }}$ Century"The Guardian, Wednesday, June $9^{\text {th }}$.

[5]Akubue, A.U., (1991). Classroom Organization and Management. Ibadan: Wisdom Publishers Ltd.

[6] Caruso, J.J., M. Temple Fawcett, 1999. "Supervision in Early Childhood Education-A developmental Perspective, Second Edition". Cultural \& Linguistically Appropriate Services.
[7] Coventry, A., "Types of Early Childhood Education Programs".

[8] David P. Weikart, (2000). "Early childhood education: need and opportunity". United Nation Educational, Scientific and Cultural Organization (UNESCO).

[9]Dipa Sinha and Vandana Bhatia, 2009. "Learning from Modelsof ECCD Provision in India”. (presented to Kusuma Foundation).

[10] Ejiogu, A.M (1990). Educational Management: A systems Approach, Lagos: Lantern Books Ltd.

[11] Federal Ministry of Education, 2005. Nigeria Education Sector Diagnosis". A condensed version, a Framework for Re-engineering the Education Sector.Education sector analysis unit.

[12] Federal Republic of Nigeria, (2004). National Policy on Education Abuja: NERDC.

[12] Goldhammer, R. (1980). Clinical Supervision $2^{\text {nd }}$ ed. New York: Holt, Rinehart and Winston.

[13] Head start Bulletin, 2001. "Cheklist for Early Childhood Curriculum". Head start Bulletin 67, HHS/ACF/ACYF/HSB. 2001. English.

[14] Lazar, A., and Slostad, F., (1999). "How to overcome obstacles to parent-teacher partnerships.' The Clearing House, 72(4), 206-211.

[15] Lockheed, M.E, and A.M Verspooretal, (1990). Improving Primary Education in Developing Countries: A Review of policy options, Washington DC.

[16] Ministry of Education Trinidad and Tobago, 2006.

[17] National Association for the Education of Young Children, Washington, DC. 1991"Facility Design for Early Childhood Programs".

[18] Government of the republic of Trinidad and Tobago, "National Early Childhood Care and Education Curriculum Guide".

[19] Nigerian Educational Research and Development Council. "National Minimum Standard for Early Childhood Care Centers in Nigeria".

[20] Nwagbara, A.C., (1998). "Towards Effective Supervision in Schools for Improved Quality of Education 
in the next Millennium" African Journal of Education Vol.2 No.1

[21] Nwagwu, N., Ehiamentlor, E. Ogunun, $\mathrm{M}$ and Nwadiani M., (2001). Current issues in educational management in Nigeria. Publication of Nigerian Association for Educational Administration and Planning (NAEPS).

[22] Nwangwu, N. A., Ijeoma, M.E.\&Nwangwu, C.C. (Edus.), (2004). Organisation and Administration: Perspectives and Practices. Benin City: Festa Printing Press Ltd.

[23] OECD Publishing, 2006. "Starting strong I\& II Early Childhood Education and Care"

[24] Okeke, B.S., (2001). Quality Management and National Goal Attainment in Education.The case of Nigeria an Inaugural Lecture Series No. 28 of University of Port Harcourt.

[25]Peretomode, V.F. (Ed.), (1995). Introduction to Educational Administration Planning and Supervision. Lagos: Joja Educational Research and Publishers Ltd.

[26] Peretomode, V.F. (Ed.). (2004). Introduction to Educational Administration Planning and Supervision. Lagos: Joja Educational Research and Publishers Ltd.

[27] The Forman School, "Strategies for helping early childhood students learn appropriate teaching practices. (Teaching Strategies).

[28] UNESCO and COUNCIL of EUROPE, 2007. Education of Roma children in Europe. "Towardsquality education for Roma children: transition from early childhood to primary education"

[29] UNESCO International Bureau of Education (IBE), 2006. "Nigeria Early Childhood Care and Education (ECCE) programmes. " Geneva, (Switzerland).

[30] UNESCO 2008, "The contribution of early childhood education for a sustainable society."

[31]Udeozor, R.K., (2004). Educational administration: perspectives and practical implications. Nimo: Rex Charles and Patrick Ltd.

[32] Ukeje, B. O., Akabogu, G. C and Ndu, A. N., (1992). Educational Administration Enugu: Fourth Dimension Publishing Co. Ltd.
[33] Wiles, K., (1992). Supervision for better Schools, Eaglewood Cliffs, NJ: Prentice-Hall, Inc. 